\title{
METHODICAL AND TECHNOLOGICAL ASSUMPTIONS FOR USING OF THE PARTICIPATORY GIS METHOD IN PLANNING AND REVITALIZATION OF URBAN GREEN SPACE (part 1)
}

\author{
${ }^{1}$ Department of Geomatics and Cartography, Faculty of Earth Sciences, Nicolaus Copernicus University, \\ Lwowska Str. 1,87-100 Toruń, kamila.walenciak@o2.pl, korzen@umk.p1 \\ ${ }^{2}$ Department of Landscape Architecture, Faculty of Environmental Management and Agriculture, \\ University of Warmia and Mazury in Olsztyn, Prawocheńskiego Str. 17, 10-727 Olsztyn, \\ mariusz.antolak@uwm.edu.pl
}

Keywords: softGIS, geosurvey, volunteered geographic information (VGI), participatory GIS, public participation, landscape architecture, spatial planning, PostGIS, Django, webGIS, social shaping of urban space

\begin{abstract}
The growth of volunteered geographic information (VGI) has opened new possibilities for citizen participation in shaping the spatial policy of cities. Data are placed on maps by means of applications that can be accessed by widely available Internet browsers. The cradle of Internet Crowdsourcing application in spatial planning is Finland. The softGIS method, involving geographic data collection with the use of geo-questionnaires placed on the maps was developed there. Currently, in Poland, the potential of this kind of practice is recognized by more and more institutions and organizations.

This paper presents the background of the author's project (some issues in social urban space shaping) and the methodical and technological aspect of the survey. The project deals with the issues of planning and revitalization of Olsztyn urban green space with the use of the participatory GIS method (softGIS). A web application in the form of a softGIS questionnaire was designed and created for the study. The online survey, under the promotional slogan "Have Influence on Olsztyn Green Space!", was conducted from mid-October 2014 until the end of January 2015. On geoankietaolsztyn.pl website the respondents (residents of Olsztyn and the neighbourhood) expressed their opinions about green spaces and recreational areas in the city. On the basis of volunteered geographic information, analyses of urban open space perception have been made at three scales: the city, the housing estate, nearby surroundings ${ }^{1}$.

The study serves, to a large extent, to shape the social importance of urban green spaces in the City. In accordance with the principle of Danish architect, Jan Gehl, "First we shape the city - then it shapes us" - the public space shall be people friendly, attract and retain them for a longer time. It shall invite residents to various activities. They can provide valuable feedback on urban space, which combined with expert knowledge can result in very well-designed surroundings.
\end{abstract}

\section{ZALOŻENIA METODYCZNO-TECHNOLOGICZNE ZASTOSOWANIA GIS'u PARTYCYPACYJNEGO DO PROJEKTOWANIA I REWITALIZACJI TERENÓW ZIELENI MIEJSKIEJ (cz. 1)}

Słowa kluczowe: softGIS, geoankieta, wolontariacka informacja geograficzna, GIS partycypacyjny, partycypacja społeczna, architektura krajobrazu, planowanie przestrzenne, PostGIS, Django, webGIS, społeczne kształtowanie przestrzeni

\footnotetext{
1 The results of analyses are presented in a separate article entitled: "Some issues in planning and revitalization of urban green space in the light of use of the participatory GIS method based on Olsztyn geosurvey - study results (part 2)"
} 


\begin{abstract}
Abstrakt
Rozwój wolontariackiej informacji geograficznej otworzył nowe możliwości partycypacji społecznej obywateli w kształtowaniu polityki przestrzennej miasta. Dane umieszczane są na mapach za pomocą aplikacji, do których dostęp jest możliwy poprzez powszechnie dostępne przeglądarki internetowe. Kolebką wykorzystania internetowych danych społecznościowych w planowaniu przestrzennym jest Finlandia. To tu opracowana została metoda softGIS, polegająca na pozyskiwaniu danych geograficznych od mieszkańców i użytkowników przestrzeni za pomocą geoankiet, czyli kwestionariuszy umieszczonych na mapach. Aktualnie w Polsce potencjał tego rodzaju praktyk dostrzega coraz więcej instytucji i organizacji.

Artykuł prezentuje przesłanki (problematykę społecznego kształtowania przestrzeni) oraz aspekt metodyczny i technologiczny badania, dotyczącego problematyki projektowania i rewitalizacji zielonej przestrzeni miejskiej Olsztyna przy zastosowaniu metody GIS'u partycypacyjnego (softGIS). Na potrzeby badania została zaprojektowana i utworzona aplikacja internetowa w postaci geoankiety. Badanie internetowe, pod hasłem promocyjnym „Wpłyń na zielony Olsztyn!” przeprowadzono od połowy października 2014 r. do końca stycznia 2015 r. Na stronie geoankietaolsztyn.pl respondenci (mieszkańcy Olsztyna i okolic) wyrażali swoje opnie i oceny odnośnie zielonej przestrzeni i miejsc rekreacji w mieście. Na podstawie wolontariackiej informacji geograficznej zostały dokonane analizy przestrzenne percepcji zieleni miejskiej na poziomie trzech skal: miasto, osiedle, najbliższa okolica.

Badanie służy w znacznej mierze kształtowaniu znaczenia społecznego terenów zieleni w mieście. Zgodnie z zasadą duńskiego architekta Jana Gehla "najpierw my kształtujemy miasta - potem one kształtują nas" - przestrzeń publiczna powinna być dla ludzi przyjazna, ma ich przyciągać i zatrzymać na dłużej. Powinna zapraszać do różnego rodzaju aktywności. Mieszkańcy mogą dostarczyć cennych informacji na temat przestrzeni miejskiej, które w połączeniu z wiedzą ekspercką mogą zaowocować bardzo dobrze zaprojektowanym otoczeniem.
\end{abstract}

\section{INTRODUCTION}

Inclusion of residents in the process of shaping urban space or the broadly understood spatial planning is not new. In addition to the obligation to consult environmental issues ( $3^{\text {rd }}$ October 2008 Act on the provision of information about the environment and its protection, public participation in environmental protection and environmental impact assessment) and spatial planning (27 $7^{\text {th }}$ March 2003 Act on spatial planning), there exists the possibility to hold consultations with local residents on the so-called important matters (Act of $8^{\text {th }}$ March 1990 on local self-government). What constitutes an important matter for a commune is usually decided by its authorities and it is them, first of all, who are responsible for initiating these consultations. In many cities, there are online communication platforms available thanks to which residents can learn about planned investments and projects, take an active part in forum discussions and get information about public consultations. In the case of green spaces, typically it is the parks or other large developed areas that are among the consulted investments and projects. It is justified by the fact that they are usually generally accessible for all residents and are important for them and the cities. As a result, green areas that are not parks (particularly those within housing estates, in-between buildings) are often wrongly overlooked and treated marginally, even though they are invaluable for residents' everyday life, their well-being, as well as for the quality of urban space, particularly in the closest vicinity of places of residence. It is unreasonable, however, to expect that consultations are held each time an urban space undergoes a change. Still, there are other methods and tools that allow to get to know residents' opinions, needs and preferences with reference to urban space.

Since most of the necessary data are of spatial nature, it seems that the most practical tools are those used for collection, storage, analysis, and sharing of spatial data associated with geographical information systems (GIS) and employing information mapping, whose example is the softGIS method that was used in this research.

\section{SOCIAL SHAPING OF URBAN SPACE - PROJECT BACKGROUND}

The choice of the study's subject matter was first and foremost motivated by the noticeable increase in the residents' (users) involvement in matters that are important both for the city and for themselves, including bottom-up participatory actions that are usually a response to decreasing urban green areas. People are more and more aware of their rights, increasingly willing to be a part of the decision-making process, and even to participate in various projects. Public participation in shaping public space is the inclusion of non-professionals in the process of creating and implementing spatial projects (Pawłowska 2010a). There are many 
methods of participation that can be used in the planning process. The most effective ones include: surveys, interviews, observational research, project workshops, brainstorming, online surveys. The latter are becoming more and more popular, among other things, due to the easy access to information they provide. What is more, the development of technology is so fast, there appear more and more possibilities to use them in various projects and adapt them to individual needs.

Taking the above into account and in view of the growing popularity of the internet, the increased use of geographic information systems (GIS) in spatial planning as well as management of urban space, it was decided that this tool has the chance to be widely employed in the city of Olsztyn.

The research is for the most part concerned with the development of social importance of green areas planning in the city. Appearance and visual aspects are important, but they cannot overshadow the practical ones. The health-related, biological, ecological or protective advantages of green areas in a city cannot be overstated. However, even though the social awareness of the above exists, these values are often underestimated. This is mostly because green areas do not generate tangible benefits, and their general value in terms of nature - which, de facto, is the most important one in the long-term process - as a rule is not measurable for people. What could be measurable, however, is the social significance of green areas in the city, which results, for example, in the increased number of users of the said space, their well-being and satisfaction.

Urban space shall be designed in such a way as to correspond to residents' needs and to exist for them. Jan Gehl (2001, 2014), Danish architect and urban planner, devotes a lot of attention to this issue. According to him, the better urban space is, the more often it is used. This applies both to large and small spaces, even as small as a single bench or a seat. "First, we shape the cities - then, they shape us" (Gehl 2014). Urban space is supposed to be people-friendly, so as to attract residents' and make them want to stay there. It shall encourage all sorts of activities, which, in turn, allow to measure the quality of space, reflecting the social preferences with regard to its use. Gehl claims that improvement of quality of public space contributes, in particular, to increased voluntary activities (choice), i.e. recreation activities, such as, for example, taking walks or resting on a bench. Increased activity encour- ages increased social activities, which cover all types of interpersonal communication (that is, those requiring the presence of others).

The socio-cultural aspect of space has been long an object of study. Scholars were looking for the factors determining social perception of space, in order to set out its key qualitative features (Januchta-Szostak 2012). According to Bronenberg (2007), the conditions on which depends the high quality of public spaces are: good communication, good maintenance, good management and easy adaptation to the different functional requirements and needs of different user groups.

Kęsek (2010) described the requirements of contemporary users of public space. They include: good accessibility, rich range of services, high security, privacy and calm surroundings (but at the same time, opportunity to be among other people), suitable public space amenities and attractive appearance of those. Januchta-Szostak (2011) proposed yet another set of key features for good public space. This set, known as IDEKWA, includes: integrity, accessibility, educational values, comfort and safety of use, image of the place and its functional attractiveness.

The above-described sets of features determining social reception of public spaces are interconnected but they also complement each other. Based on the analysis of desirable qualities of urban space and their adaptation to the subject matter selected, the author proposed a set of diagnostic features for the needs of the research. These features were used, first and foremost, for assessment of the closest surroundings of residential areas, since, according to the author, average residents have the best knowledge of those areas they spend most of their time in or feel closely connected to.

The social value of the research also includes its participatory aspect. According to Gehl (2001), the quality of medieval cities was due to the fact that they were planned by their users rather than designers contracted by rich rulers or investors. This is why, later on, very few urban spaces have been characterized by a similar quality.

Perception of the outside world, urban spaces included, takes place based on the stimuli received by the human senses (Kantarek A. A. 2008). The human process of exploring space takes place on two planes. People seek to obtain general knowledge about selected spatial entities (place, neighbourhood, district, city). They need to do it in order to organize their activities within the space and make the right decisions. At the 
same time, throughout their whole life, a person is constantly becoming familiar with their immediate surroundings. Memories of the previously known spaces are important for this recognition, and the understanding of the space a person is surrounded by is the basic principle on which human existence is based (Mordwa 2009: after Wallis 1990).

Diversity of perceptions and attitudes towards a given space is the most common source of interpersonal conflicts in the process of spatial planning. Responsible and careful shaping of space consists in, as far as possible, taking into account the needs of its users ("Laymen can provide valuable information on the space" Goodchild, 2007), which, combined with the expertise can result in a very well designed environment. Improperly planned green areas can affect the quality of the environment (Chmielewski 2001).

Pawłowska (2010a) stresses that many individuals and groups of people with various points of view shall have the right to participate in making decisions on a given public space. The trick is to work out a compromise in the form of an optimal solution to the problem. What is important, "studies on landscape perception carried out for architectural purposes tend to objectify professional opinions or to recognize social perception".

The objective of the research corresponds with both of these tasks.

\section{PARTICIPATORY GIS AND THE SOFTGIS METHOD}

The idea of participatory GIS (PPGIS, public participation GIS) was born in 1996 in a scientific consortium of the National Center for Geographic Information and Analysis (NCGIA 1996), where a new generation of GIS was presented, together with the new possibilities to use geographic information systems. The main goal was to ground technological progress in the social and political context, and the reason behind the whole enterprise was the participation of local communities in the decision-making process.

Participatory GIS is a situation when residents are involved in the acquisition, processing, analysis and visualization of geographic data (NCGIA 1996, R. Sieber 2006). Digitally acquired data are used as additional layers of information, they can be easily integrated with them, as well as incorporated into the municipal geographic information systems. This way, they can complement the data on infrastructure and legal status ("hard data") with data on perceptions, evaluations and activities of residents, known as "soft data" (M. Czepkiewicz, 2013). The latter are the volunteered geographic information and constitute the so-called bottom-up GIS (E. Talen, 2000).

One method of participatory GIS is the softGIS method, developed at the Aalto University in Helsinki (M. Kahila and M. Kyttä 2010). It involves acquiring geographic data from users of public spaces, using the so-called geosurveys, that is, online questionnaires placed on maps. This method is commonly used by the planning offices in Finland. It allows to obtain large amounts of data, diagnose the space and study the social needs at early stages of planning. It was the authors' intention for this method to be a bridge between the planners and the residents (Kahil and Kyttä 2010).

\section{STRUCTURE OF GEOSURVEY}

In order to meet the objective of the research, an original new tool was developed, that allows to get to know opinions, needs and preferences of residents in relation to green urban spaces, and which allows, at the same time, to use the obtained data in the planning or revitalisation process. Due to the fact that the selected content of the survey influences the type of results and their subsequent analyses, designing the questionnaire's structure was a very important stage of research. Preparations of the geosurvey began in August 2014. Having analysed several traditional surveys related to the shaping of urban green spaces, as well as several online platforms, both domestic and foreign, that use the softGIS method, as well as having reviewed the methodology of the surveys, the questionnaire's structure was developed that corresponds perfectly to the intended purpose.

Important methodical support came from a book edited by Krystyna Pawłowska, entitled: "Before conflict breaks out: idea and participation methods in the protection of landscape and public space shaping" (2010 $a$ and $b$ ). One of the social participation methods discussed therein is a survey. The author presents relevant guidelines for constructing a questionnaire and asking questions in surveys that serve to prepare the design process. According to Pawłowska, four groups of questions are typically asked in these surveys, which are concerned with: respondents' opinions on the existing conditions, 
opinions on the nature and extent of changes, requests for design ideas, opinions about the designer's ideas.

For the purposes of this research on urban green spaces within the city of Olsztyn, whose goal was to formulate planning guidelines, the first three groups of questions were applied. The fourth group of questions refers to the surveys drawn up for the purposes of consulting the already developed design concepts, for example, the general ideas for introducing green areas into a given residential estate, or developing a park or a square.

According to Pawłowska (2010b), the acceptance for current functional destinations can support the idea of protection and conservation of important, unchanging values or an inspiration for a concept based on continuing a tradition. Negative ratings, on the other hand, are an important argument in favour of change.

The second group of questions, concerned with opinions on the character and extent of changes, is necessary in order to examine the residents' needs and to identify conflict areas. The third group of questions gives respondents the possibility to suggest specific planning solutions, for example, indicate types of plants or small architecture amenities that shall appear in a particular site.

With this in mind, the following original questionnaire was created. The geosurvey consists of eight stages (pages). The first stage is a welcome and invitation page of the survey, where the respondent is briefly acquainted with the problem and the reasons behind the survey. Stages from second to sixth (pages from 1 to $5^{2}$ ) are supplemented with an interactive map that can be navigated on and where sites can be marked. Once a site is selected, a survey will appear, with questions corresponding to the current stage. This form can be deleted or saved. As a result of saving, provided the form has been filled in correctly, the user will return to the first screen of a given stage. As a result of deleting, the selections already made will disappear from the survey.

Survey contents in stages two to six are divided into three main thematic blocks, containing different categories of questions. These are:

On pages 1 and 2: POSITIVE, FRIENDLY, IMPORTANT PLACES:

- places to spend free time in;

- other valuable and important places.

\footnotetext{
2 The adopted page numbering starts from stage 2 , that is the introductory page is not numbered.
}

In both these categories, in addition to the closed, semi-open-ended and open-ended questions, the socalled questions on the scale were also asked. To rate specific sites in both groups, consistent categories of questions were applied. With the use of a 6-grade scale (with the following options: "no opinion", "very little", "little", "some", "considerable", "crucial"), the indicated places are assessed in terms of:

- relevance for urban order;

- environmental assets;

- historical and cultural values;

- social values (leisure and recreation);

- representative significance.

In 3 and 4: NEGATIVE, HOSTILE PLACES AND THOSE IN NEED OF CHANGES:

- places with no green spaces;

- places in need of changes other than adding green spaces (fig. 1), that is, places rated negatively due to:

- lack of recreation facilities for children/playgrounds;

- lack of sport and recreation amenities for young people and adults (e.g. outdoor gyms, skate parks, board game tables, chess or ping pong tables);

- lack of small architecture amenities (e.g., litter bins, benches, light fixtures, etc.);

- lacking or poorly planned traffic infrastructure (mainly concerning walking and cycling paths);

- neglected, poorly maintained green spaces, no aesthetic values;

- no sense of security;

- other than the above.

Page 5 of the survey is the next thematic block: CLOSEST AREA together with the site of the place of residence and rating of the neighbourhood in terms of five factors (research indicators) - number of green spaces, their quality, leisure possibilities (amenities for rest and recreation), security and spatial order (aesthetics). The second question on the given page is the general satisfaction of respondents with the surroundings of their place of residence. In both cases, a five-grade scale was used for rating.

Pages 6 and 7 contain ADDITIONAL INFORMATION (general questions about green spaces in Olsztyn and a legend), as well as the CONCLUSION (possibility to add comments about issues that were not addressed in the survey and a thank-you note for participation). 


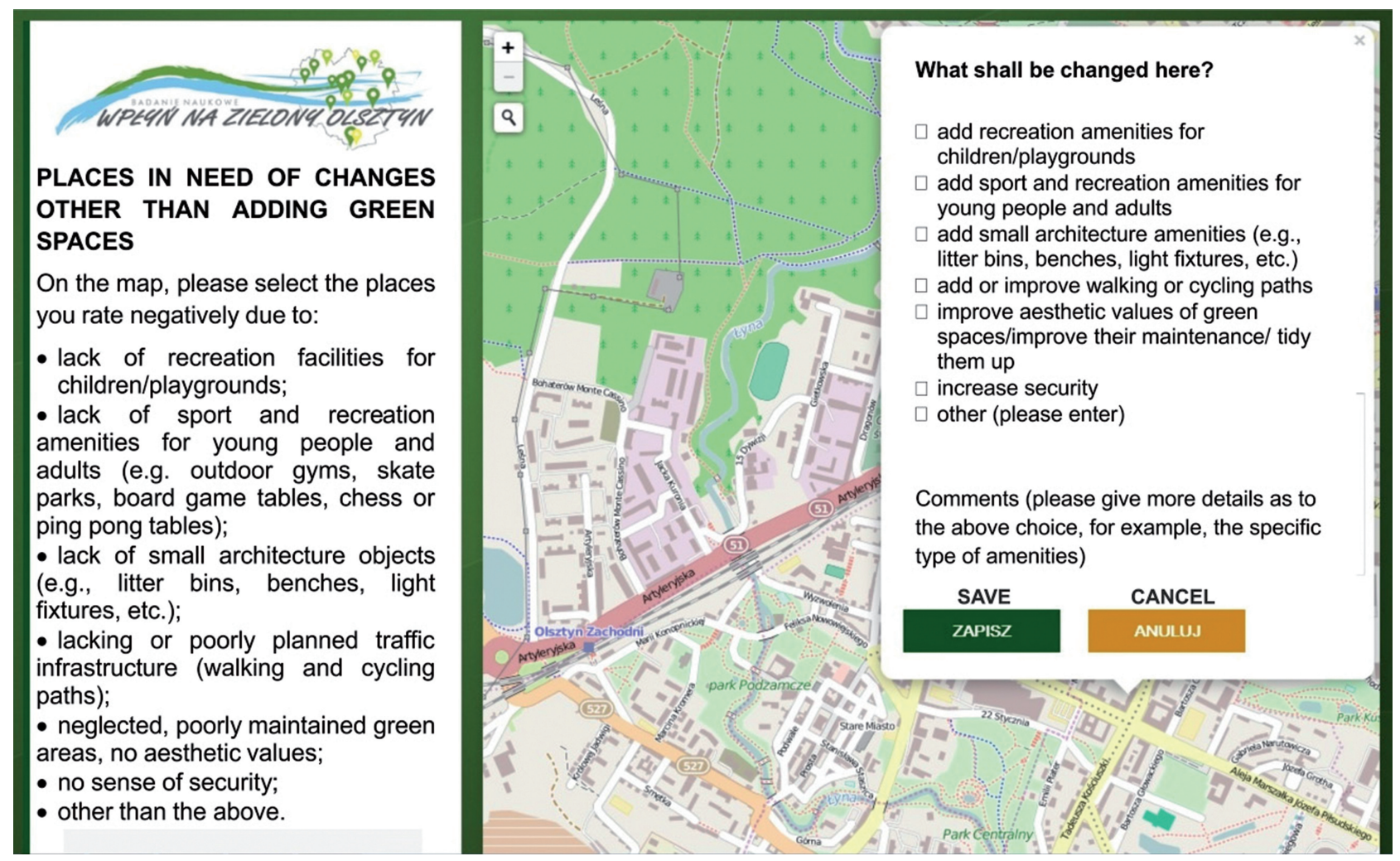

Fig. 1. Sample geosurvey questionnaire - page 4 (screenshot)

Rys. 1. Przykładowy kwestionariusz geoankiety - karta 4 (zrzut ekranu)

\section{ONLINE APPLICATION - TECHNOLOGICAL ASPECT OF THE PROJECT}

The tool used for research was an application a geosurvey available at http://geoankietaolsztyn.pl. The app, implemented using client-server architecture, consisted of three components: database, web server, and user interface (in a web browser).

The lowest layer of the project, that is, handling of HTTP requests Hypertext Transfer Protocol) was implemented with the use of the Django framework. From the programmer's point of view, it is a high-level Python library, offering a framework that allows to create quickly web applications (Kropiewnicki 2008). A web browser, the server's client, connects to the web server, and downloads a website (Fig. 2).

The Django framework, running on a web server, acts like a bridge between the online app (client), server, and database. The framework communicates with the database, using object-relational mapping, which maps an object-oriented architecture of an IT system to a relational database $\left(S Q L^{3}\right)$.

In line with its purpose, the geosurvey project uses a powerful PostgreSQL database with an object-relational PostGIS extension. As a result, it is possible to save geographic data directly into the database, according to the OpenGIS Simple Features ${ }^{4}$ specification for the SQL profile. In addition, PostGIS allows to process geographic data collected, using spatial predicates that examine: geometric relationships between objects, spa-

${ }^{3} \mathrm{SQL}$ - structured query language, used in programming to create and modify databases, and to store and retrieve data from databases (Wikipedia).

${ }^{4}$ Simple Feature - one of the spatial information exchange standards. This information is developed, implemented and made available by the international Open Geospatial Consortium (OGC). This standard, essential for interoperability, describes how geographic data are stored digitally, together with their spatial and non-spatial attributes. The word "simple" refers to the two-dimensional geometry used by the standard, in which objects do not intersect in any way. Spatial extensions of databases, such as PostGIS, are based on this standard (Rzeszewski, Jasiewicz 2009). 


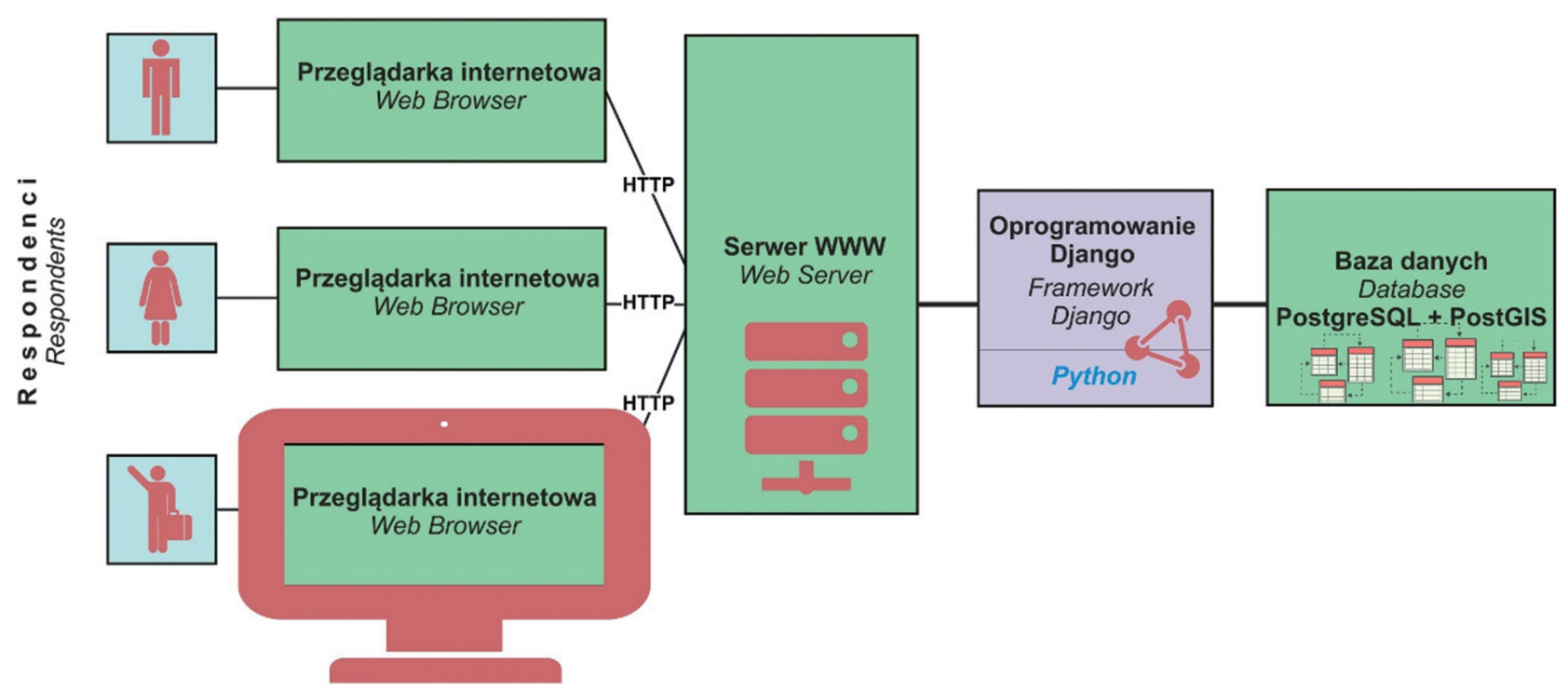

Fig. 2. Chart presenting the client's (user) communication with web browser and Django via a HTTP protocol Rys. 2. Schemat komunikacji klienta (użytkownika) z serwerem WWW i Django poprzez protokół http

tial operators and spatial operations conducted on data sets (Rzeszewski, Jasiewicz 2009).

The Django framework applied in the project also provides a user-friendly admin panel, from which the author could easily manage the project, preview collected results in real time, define new objects, establish relationships between them, as well as carry out defined actions, i.e. export data.

In the "Sites" tab, there is a list of selected places together with their IDs. From there, it is possible to verify the data. Preview of position of a given site marker on the map allows to assess initially the suitability or reliability of the data, for example, by verifying that the point is located within the administrative borders of the city. It is also possible to edit the positions of sites, remove them, as well as add new ones (fig. 3).

In the "Users" tab, there is a list of IDs of all users who opened the survey's web page, that is, not necessarily those who took part in it. Viewing of each page is documented by a unique session key given to the user. Next to the ID, basic user information is displayed, such as: sex and age of the respondent (visible if filled in earlier in the survey) and the date of beginning and end of the survey. This makes it possible to determine the dominant group of respondents (men and women in a specific age group) and the average time spent by users to participate in the survey.
The "Result" tab shows the accumulated results broken down into seven thematic categories, corresponding to those contained in the individual steps of the survey. In each category, a list of sites IDs can be viewed, as well as user profiles (IP address, ID of session, age and gender), and a map with preview of specific sites. Each spatial information has the correct descriptive information (attributes) assigned to it, which make up answers to the questions from the survey forms. In every case, subsequent answers to a given question are assigned points, numbered, starting from 1. Multiple choices of answers are separated in the table with a semicolon. In order to answer open-ended questions, the respondent enters the entire text into the prepared text boxes, using the client application. In order to compare results from different levels of the project, graphics, depicting respondent's answer for the selected site were prepared (ID 894) in the third category of questions - places in shortage of green areas. Figure 4 shows questions and answers as seen by the respondent, using a web browser, Figure 5 shows the same questions and answers in the form of attributes, as seen from the Admin Panel.

Export of data to dbf, .prj, .SHP and .SHx files is done with the use of the pgsql2shp application, which is an integral part of the PostgreSQL database with PostGIS package. A Python script allows for .zip file archiving and sharing the final database dump in the 


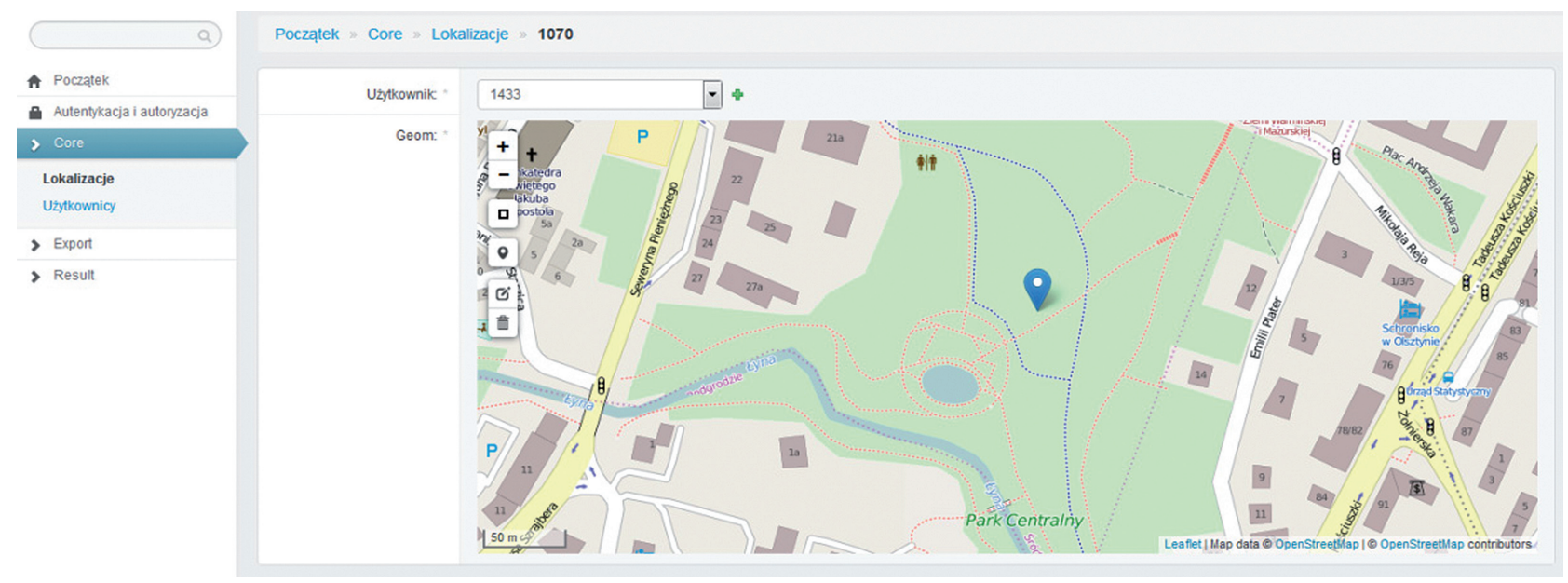

Fig. 3. View of admin panel with preview of marker's location on the map

Rys. 3. Widok Panelu administratora z podglądem położenia markera na mapie

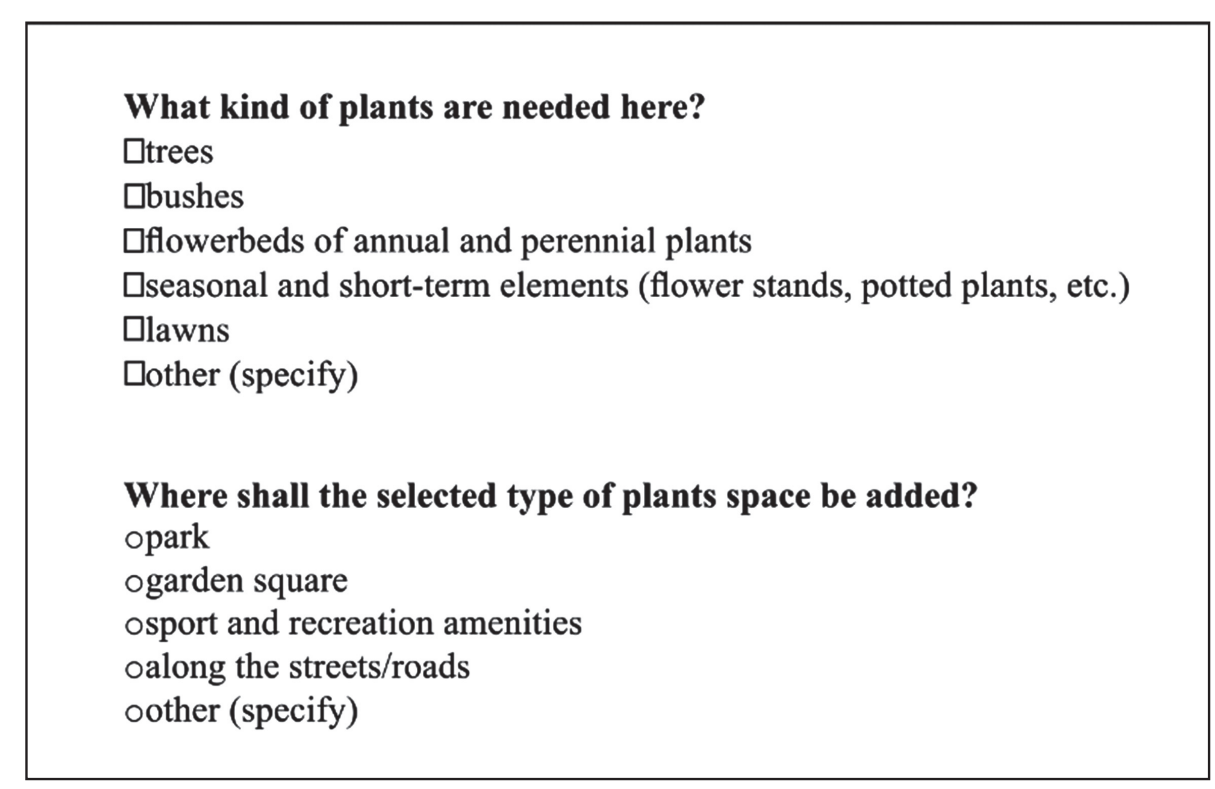

Fig. 4. View of questions and answers, as seen using a web browser (Category: Places in shortage of green areas - site 894) Rys. 4. Widok pytań i odpowiedzi od strony przeglądarki internetowej (Kategoria: Miejsca, w których brakuje zieleni - lokalizacja 894)

admin panel. In the "Export" tab of the Panel, there is a list of all the database dumps generated, together with their generation dates. This makes it possible to access survey results from a given day of the survey's duration. An archived file can be quickly and easily downloaded to a PC. Once the files have been extracted, 9 output tables become available, that were mentioned earlier, when discussing "core" and "result" application.
The client application uses Django to handle AJAX (Asynchronous JavaScript and XML), asynchronous JavaScript and XML) requests. This is a technique of creating web applications, in which the user interacts with the server without reloading the entire document. In this way, survey forms filled in by the user save the data from each stage and allow for a two-way navigation (Next Step/Previous Step). 


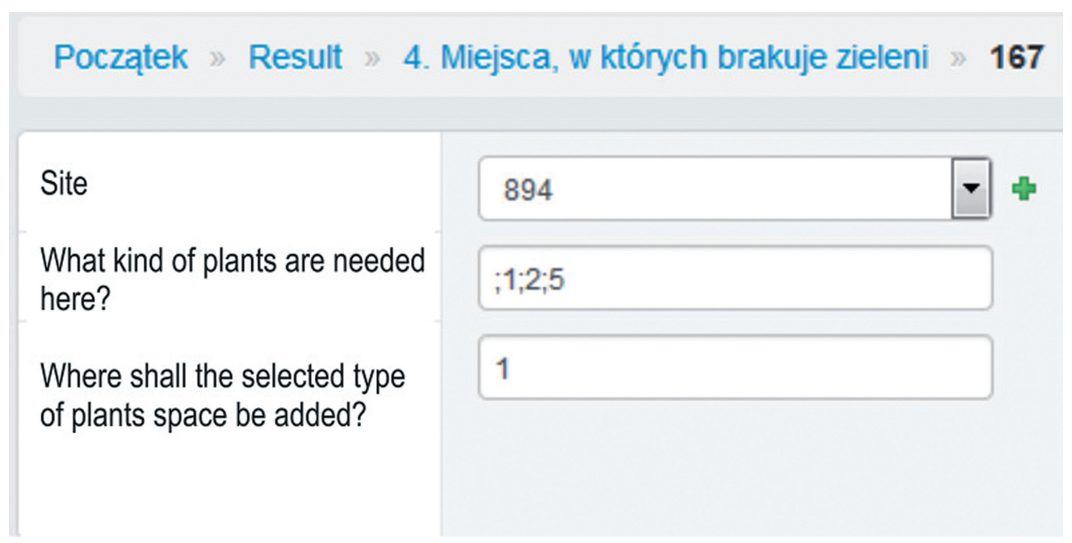

Fig. 5. View questions and answers as seen from the Admin Panel (Category: Places in shortage of green areas - site 894) Rys. 5. Widok pytań i odpowiedzi od strony Panelu administratora (Kategoria: Miejsca, w których brakuje zieleni - lokalizacja 894)

jQuery library, created in the JavaScript programming language, was used to support ajax queries, dynamic changes of the page contents and the validation of input data. To display data, forms and media, the latest HTML5 and CSS3 internet standards were used.

The map's interface and user interaction are based on the URLeaflet.js library, which fixes the issue with displaying the interactive map on the website. This library uses the OpenStreetMap maps, allows to use descriptive layers, put user's own lines, markers and geometric figures on the map (in the survey - points), to overlay images, resize maps (this can be also done with a double click and mouse wheel), as well as drag and drop them, add pop-up messages (in the survey - in the form of survey forms) or to configure one's own user interface. The combination of URLeaflet.js, jQuery and AJAX allows for dynamic saving of spatial data in the database, which were extracted from selected markers (points) on the map and the contents of forms assigned in a given stage of the survey.

\section{PROMOTION OF THE SURVEY AS AN IMPORTANT ELEMENT OF THE RESEARCH PROCESS}

As soon as the internet application was launched, the promotion of the survey started as well, in order to reach the biggest possible number of respondents. It is a very important element of public participation. In the process of participatory designing and revitalization of urban spaces, where the main objective is to obtain inspiration and detect potential conflicts and problem areas, acquiring spatial data is the key issue. And even though this type of research does not need to be based on a representative sample, since approximate results are sufficient here (Pawłowska 2010b), one must collect the kind of data which will allow to draw conclusions that are substantive for the purpose of the undertaking stipulated at the beginning of the survey. Considering that participation in research and various forms of participation is voluntary, and in the case of online surveys, it is limited by the access to the Internet, it is critical to advertise the possibility of shared decision-making to the biggest possible fraction of the test group, that is, the case of the project in question, the residents of Olsztyn and its vicinity. In view of the fact that the implementation of the research tasks of this study is based on the actual experimental survey, its promotional stage is extremely important and necessary for the implementation of these tasks.

Over the four months of online data collection, the author of this project regularly attempted (independently) to take various initiatives to promote the project, particularly those employing free distribution channels. A period of about three weeks (in December 2014), during which no advertising or outreach actions were taken was an exception. It was observed that the interest in the project decreased considerably during that period, or was not present at all (no data of impact).

Advertising actions started in August 2014, from creating the project's logos and its promotional slogan. Elements of visual identification of the study were sup- 
posed to highlight its subject matter and the fact that respondents shall have an actual possibility to participate in shaping the urban space. They were used repeatedly throughout the duration of the study.

The promotional activities carried out can be divided into not internet-based or online ones. Among the first, there were: preparation and distribution of more than 200 business cards, promotional lectures at the University of Varmia and Masuria, ads in the local press, presentation of the object of research during academic conferences. However, most promotional activities were carried out online. As it turned out later, these activities brought about the most successful results in the form of a large number of responses (selections) saved in the database. Since it is difficult to control the spread of information in the internet, particularly in the era of social media, only the main activities, promoting the survey were presented below. These include:

- launching and running a Facebook page for the survey;

- advertising the survey by local communities, associations, social workers of the city and the local internet press;

- publishing online articles, with information about the reasons behind the study, its purpose and scope, public consultations and their alternatives;

- invitations to participate in the study, sent via email.

Based on observations of the study and the inflow of results in the period from $11^{\text {th }}$ October 2014 to $24^{\text {th }}$ February 2015, an assessment of effectiveness of the above-mentioned promotional activities was made. The main factors of assessment were the type of advertising media and the potential target group. It was found out that the most effective advertising and promotion medium was the Internet, which currently constitutes one of the most important media and is an easily available source of information. When a respondent reads the information off traditional press or a leaflet, they need to memorise it first in order to open the website later. Online message with a direct link to the survey allows for an immediate response. Facebook turned out to be particularly important for the promotion of the project. Not only do social networking sites provide information about participation possibilities, but they also allow to create an online community (however, it is not guaranteed) that develops gradually, starting from the interest taken in the matter in question, to a genuine involvement. They allow organisers of participatory actions to get in touch with participants, and participants can get in touch with each other (Pawłowska 2010b).

As regards the target group that was to be reached, a certain regularity was observed. When the information on the project is shared online by specific communities whose interests or areas of operation are consistent with the project's objective, it is a lot more popular than when it is being shared, for example, on the main profile, next to events from different areas. That is why it is important for the implementation of participatory projects to determine not so much a representative group for the city's population (a research sample), but groups or communities that could encourage residents, owing to being respected, to take an active part in this project, since they can influence many of them.

In the case of projects related to planning and revitalization of urban space, the target groups will certainly be all organizations and associations who pursue various social actions and initiatives that represent interests of residents in the projects planned by the city authorities, and who suggest and support social activity of the residents of the city, in order to build civil society. Other groups of people likely to provide support are district councils, environmentalists, biologists, researchers, particularly those who promote the idea of sustainable urban development in their research.

The "snowballing" effect is worth mentioning here. According to Pawłowska (2010b), when encouraging people who know each other to participate, first, one person or a small group of people has to be recruited and then asked to promote the issue among other participants.

One has to keep in mind that any kind of promotion of a participatory project shall attract the interest of potential respondents, to a greater or lesser extent. However, given the limited time to carry out the survey and the limited number of people involved in the project, it seems reasonable to set out the preferred forms of promotion and advertising, depending on the type and scale of the project.

\section{RESEARCH CHART IN THE ANALYSIS OF OBTAINED RESULTS}

The general summary of the project was an introduction to a detailed analysis. A comprehensive overview of the obtained data revealed, first of all, the quantity 
and nature of data, and also the number and demographic structure of respondents (users of urban space). Interestingly enough, already at that stage, certain tendencies and trends were noticed, important from the point of view of a researcher who plans or designs urban spaces. The next step was a detailed verification of the data, which allowed to evaluate the quality and value of the voluntary information acquired. As far as it was possible, the reliability and authenticity of individual data were evaluated. Based on the comments and suggestions from respondents, the data were organized, according to accepted categorization. The information that was too vague, of little value, or irrelevant to the subject matter of the study was rejected from further research.

Based on the information obtained thanks to the geosurvey designed, it was possible to carry out multi-faceted research and analysis. In order to meet the objective of the research, a specific chart was proposed to use voluntary spatial information in the process of planning and revitalization of green spaces in the city. The proposed stages are:

1) Assessment of respondents' general opinion and their rating of green areas

This stage shows the opinions of users of space on the development of individual green areas in the city, as well as suggestions for changes regarding development, shaping and managing urban green areas. It serves to draw attention to the areas that are not functioning well enough and are in need of improvement, in the opinion of respondents.

2) Social valorisation of urban space based on the perception of the neighbouring area of residence This stage shows the average rating of the space in terms of a given (assumed) factor, which determines its social reception. Then, it shows the summary rating of the space, taking into account all the average ratings (or the selected ones, depending on the purpose of the study) of individual factors. It results in the valorisation of a given space, reflecting the extent of its social acceptance.

3) Analysis of detailed spatial data - respondents' suggestions for changes

This is the main and most important stage in the research process. Its implementation may supplement the two previous stages, serving to set out directions for planning and revitalization activities and to diagnose the most problematic areas within the city, or else it may be carried out independently, as part of the diagnosis of local needs of citizens. Therefore, it can be used in the process of developing individual green spaces and managing them.

4) Identification and valorisation of positive, friendly and important places in the city or housing estate

The implementation of this stage allows to identify sites favoured be the residents, places of leisure, as well as, places that are important for them, that are or could possibly be significant for the city or estate. In addition, social rating of these places in terms of the factors assumed, in combination with opinions of experts, could be successfully used when preparing plans or strategies for developing urban green spaces. The analysis of objects particularly important and valuable for the residents, along with the analysis of places rated negatively and requiring improvement, allows to draw relevant project conclusions. Objects particularly important for residents and the city require different guidelines for maintenance and use, so that they can be properly protected.

\section{5) Attempt to formulate project guidelines}

This is the last stage of the research process, which sums up all the previous stages. It consists in formulating general project guidelines (assumptions) for the entire city and detailed guidelines for selected objects within the public space (in the form of so-called land cards).

\section{SUMMARY AND CONCLUSIONS}

Regardless of how it is conducted, a participatory process of planning and revitalizing urban spaces is not easy. It requires from all those concerned a lot of commitment, flexibility, readiness for compromise and, above all, co-operative attitude. Social participation can only be successful when everybody is convinced of the common objective, which is to find an optimal solution to a given problem.

Recently, the involvement of residents in the issues related to their surroundings has increased noticeably, 
compared to the previous years. This certainly has to do with residents' greater awareness and knowledge of their own rights, as well as, with solutions that are already in use in Western Europe being brought and imitated in Poland. Alongside traditional methods (which are rarely used in Poland), these practices cover online methods, including those, using geographic information systems, an example of which has been presented in this paper.

The paper presents the stages of a research process, proposed in the original project, in the methodological and technological context. The suggested research methodology shows a great potential of geosurveys (sofGIS methods) in landscaping and spatial planning. The model of the softGIS method applied in the process of planning and revitalizing urban space is presented in Figure 6. A geosurvey may be initiated by the decision-makers (for example, during a preliminary analysis of a planned project) or by residents themselves (who wish to express their needs and suggestions regarding a given place). The geosurvey shall be tailored to the research needs and scale. It can be a stand-alone application or a tab in an urban spatial information system website, where the results are accessed and viewed by everybody in real time, as well as, provide an additional layer for the so-called hard data. Data can be collected both for small, specific projects (e.g., compensating plantings), as well as, all kinds of programmes, strategies, planning documents and larger projects of spatial planning, for which public consultations are often carried out as well. Geosurveys can be used virtually on any stage of the project - starting from its conception and planning, and ending with its management and utilisation of investment.

The tools discussed in this paper are very flexible, which makes it possible to adapt them to individual projects. As the popularity of the Internet and Geographic Information Systems grows, a geosurvey can be an excellent supplement of the public consultation methods already in use, particularly when spatial data are required. Geosurveys bring about many advantages, many of which are identical with the advantages of social participation in general. There are, however, numerous benefits of online tools (in the form of the softGIS method), that support the process of planning and revitalization of urban space, which make them superior to the traditional methods. Among them, there are, in particular:

- acquisition of large quantities of valuable social spatial data (both quantitative and qualitative) for further analyses, for example, data needed for documents which deal with green spaces shaping), without the need to digitize the data collected, for example, with the use of traditional surveys);

- acquisition of social data (the so-called "soft data") as successive layers analysed with regard to layers related to land development (the so-called "hard data", for example, the structure of ownership, technical infrastructure, etc.) - Geographic Information Systems are used more and more often in the implementation of planning documents;

- opportunity to learn about the needs of local residents in the field of non-park green spaces, for the needs of small projects which usually are not subject to social consultations (possibility to collect detailed, scattered data on the suggested sites of small architecture, sport amenities, green spaces, that would have been hard to acquire in any other way);

- scalability and flexibility of tools - the possibility to adapt them later to other participatory projects (their scale and subject matter) - the contents of geosurvey proposed in the study and the analyses carried out based on the obtained results are for reference only;

- saving residents' time - possibility to express their own needs and opinions without leaving home (convenient for users); opportunity for those who, for various reasons, cannot participate in traditional public consultations (meetings);

- mapping the information is usually an easier, more transparent and user-friendly display of information than presenting the same information by means of traditional surveys (as a description);

- the possibility to use open-source software to draw up geosurvey tools;

- the tool is innovative - various sources of innovative projects funding are possible; in addition, this new form of communication attracts users;

- possibility to expand the urban spatial information system with the geosurvey function to collect social data or, possibly, only use it to share the results of participtory projects; such information can be used by planners (especially the non-local ones, who are not familiar with the residents' needs);

- possibility to use mobile devices applications in the research, so that users can indicate specific sites while they are there. 


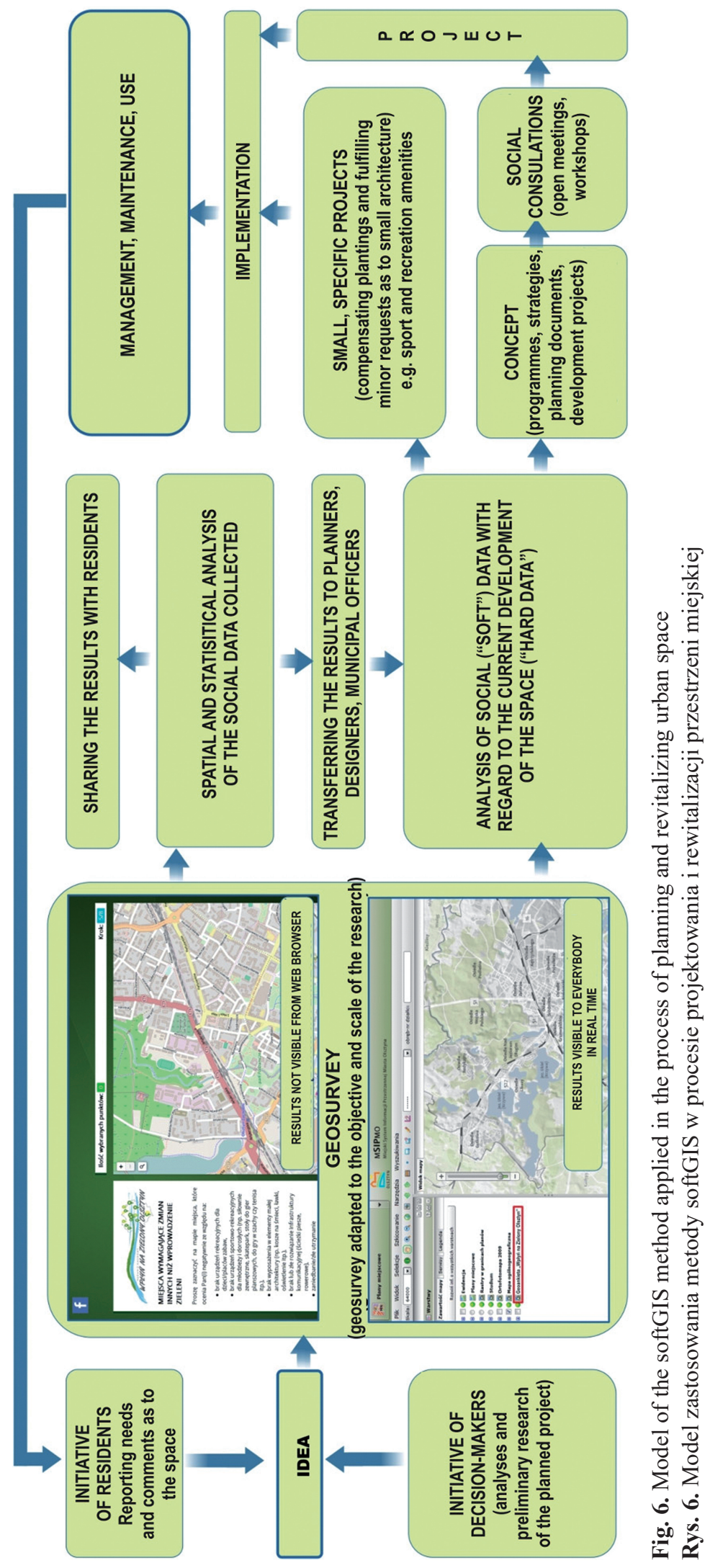


However, certain limitations (weaknesses) of the online social participation method in the form of a geosurvey have also been observed. They include mostly:

- limiting the respondent group to internet users only (despite the universality of the internet, a certain group of residents is excluded from participation in the research, particularly the seniors);

- users can become discouraged from participation in the study due to their inability to read maps or to use the application in general;

- difficulties in data acquisition (depends on the nature and intensity of the research promotion);

- it is virtually impossible to verify the reliability of data (the assumption that the voluntary nature of participation in the research, as well as filling in only chosen pages of the survey will contribute to collecting the most reliable and accurate data); however, it is also a weakness of traditional surveys (meetings or workshops, during which the practicality of ideas is reviewed on the spot, are superior here);

- time-consuming processing of a large number of data (especially the open-ended questions, however, the said research revealed that using mostly closed questions in the survey can be a source of high-quality data).

In addition, a number of methodological conclusions were made while implementing the research, useful for other projects that use similar tools. Some of them include:

- analysis of effectiveness of promotional activities and identification of the most efficient promotional media (the Internet, the social networking sites in particular) and potential recipients (local social worker groups, associations and organizations that support shaping of urban spaces with the participation of residents, naturalists);

- the unwillingness of respondents to indicate their places of residence, which was noticed urges to look for other solutions, for example, geocoding;

- it is important to select the right time for carrying out the research (the spring-summer season is favourable for research of urban green areas or broadly-understood city spaces or else the period of staying outdoor longer); the research was carried out in the autumn-winter season, which unfortunately resulted in a decreased number of incoming data over time;

- it is worth considering to limit the geosurvey to selected issues only, and possibly conducting a few other research processes independently (excess of information may discourage respondents from filling in the survey from start to finish).

The above-mentioned problems are important issues that ought to be analysed before launching the online participatory process. Despite some limitations, the softGIS method has a great potential to be used in participatory process of planning and the revitalization of urban green areas. The collected social data, along with the opinions of experts, can be invaluable for decision-making processes of the city authorities as well as planners and designers.

The implementation of various stages of research together with their results has been presented in the second part of the article, entitled "Some issues in planning and revitalization of urban green spaces in the light of use of the participatory GIS method based on Olsztyn geosurvey - study results (part 2)".

\section{BIBLIOGRAPHY}

Bronenberg W., 2007, Przestrzeń publiczna $w$ osiedlach mieszkaniowych, metoda analizy społeczno-przestrzennej, Wydział Architektury Politechniki Poznańskiej, Poznań, p. 49.

Chmielewski J. M., 2001, Teoria urbanistyki $w$ projektowaniu i planowaniu miast, Oficyna Wydawnicza Politechniki Warszawskiej, Warszawa.

Czepkiewicz M., 2013, Systemy informacji geograficznej w partycypacyjnym zarządzaniu przyroda w mieście. [w:] Zrównoważony rozwój - Zastosowania nr 4. „Przyroda w mieście - Rozwiązania”. Kraków: Fundacja Sendzimira, p. 111-123.

Gehl J., 2001, Life Between Buildings, The Danish Architectural Press, Copenhagen.

Gehl J., 2014, Miasta dla ludzi, Wydawnictwo RAM, Kraków.

Goodchild M.F., 2007, Citizens as sensors: the world of volunteered geography. GeoJournal 69(4), p. 211-221.

Hasanzadeh K., 2014, Soft GIS Data Mining and Analysis: A Case Study of Urban Impression in Helsinki (Master's Thesis),

https://aaltodoc.aalto.fi/bitstream/handle/123456789/13123/master_Hasanzadeh_Kamyar_2014.pdf?sequence $=1$ [accessed: 15.05.2015].

Januchta-Szostak A., 2011, Woda w miejskiej przestrzeni publicznej. Modelowe formy zagospodarowania wód opadowych i powierzchniowych, seria: Rozprawy nr 454, Wydawnictwo Politechniki Poznańskiej, Poznań.

Januchta-Szostak A., 2012, Atrybuty dobrej przestrzeni publicznej $w$ świetle badań jakości życia i percepcji przestrzeni 
miejskiej [w:] M. Kosmala (red.), Zieleń a klimat społeczny miasta, Polskie Zrzeszenie Inżynierów i Techników Sanitarnych Oddział Toruń, Toruń, p. 27-43.

Kahila M., Kyttä, M., 2010, Soft GIS as a bridge builder in collaborative urban planning [w:]: S. Wallin (red.), Digital tools in participatory planning, Espoo: Centre for Urban and Regional Studies Publications, p. 13-36.

Kantarek A.A., 2008, O orientacji w przestrzeni miasta, Wydawnictwo Politechniki Krakowskiej, Kraków.

Kęsek Z., 2010, Przestrzeń publiczna - współczesne oczekiwania, Czasopismo Techniczne 2-A/2010, z. 5, rok 107, Wydawnictwo Politechniki Krakowskiej, Kraków.

Kropiewnicki T., 2008, Django - Python $w$ zastosowaniach webowych. Software Developer's Journal, p. 18-25.

Mordwa S., 2010, Krzywa wrażeń dla ulicy Piotrkowskiej w Łodzi, Acta Universitatis Lodziensis. Folia Geographica SocioOeconomica 10(2010) p. 89-98.

NCGIA (National Center for Geographic Information and Analysis), 1996, Summary report: Public participation GIS workshop, Orono, ME, 10-13 July.

Pawłowska K. (red.), 2010a, Zanim wybuchnie konflikt: idea $i$ metody partycypacji w ochronie krajobrazu i ksztattowaniu przestrzeni, tom A: Dlaczego? Fundacja Partnerstwo dla Środowiska, Kraków.
Pawłowska K. (red.) 2010b, Zanim wybuchnie konflikt: idea $i$ metody partycypacji $w$ ochronie krajobrazu i ksztaltowaniu przestrzeni, tom B: Jak? Fundacja Partnerstwo dla Środowiska, Kraków.

Rzeszewski, M., Jasiewicz J., 2009, WebGIS - od map w Internecie do geoprzetwarzania [w:] Z. Zwoliński (red.), GIS platforma integracyjna geografi, Bogucki Wydawnictwo Naukowe, p. 23-33.

Schneider-Skalska G., 2006, Idea społecznościowego centrum projektowego [w:] W. Seruga (red.), Środowisko Mieszkaniowe - Housing Environment, Wydawnictwo Katedry Kształtowania Środowiska Mieszkaniowego, tom 10, Kraków, p. 6-9.

Sieber R., 2006, Public Participation Geographic Information Systems: a literature review and framework, Annals of the Association of American Geographers, 96(3), p. 491-507 .

Skiba M., 2008, Rozmyte miary percepcji krajobrazu [w:] U. Myga-Piątek, K. Pawłowska (red.), Zarządzanie krajobrazem kulturowym, Sosnowiec: Komisja Krajobrazu Kulturowego PTG, p. 123-130.

Talen E., 2000, Bottom-up GIS: a new tool for individual and group expression in participatory planning. Journal of the American Planning Association 66(3), p. 279-294. 